\title{
Women Rights and Gender Equality as Per Albanian law
}

\author{
Evelina Qirjako, Ph.D. Candidate
}

Member of Supreme Court; evelinaqirjako@gmail.com

\section{Doi:10.5901/ajis.2016.v5n1p195}

\section{Abstract}

Following the integration process with European Union, Albania has an obligation to progress on gender equality area. In this regard, Albania should develop a comprehensive legal framework and establish effective mechanisms to address and overcome gender inequalities, as well as efficient tools and concrete results for prevention of gender based violence, rehabilitation and integration of its victims, and concrete results for advancement of women rights in all sectors of life. This article provides an overview of albanian legislation on gender equality, and relevant reccomandations for intensification of institutional steps to achieve gender equality in Albania.

Keywords: gender equality; women rights; gender based violence; referal mechanism; gender discrimination; national authority for gender equality;

\section{Introduction}

Gender Equality (equality between men and women) constitutes substantial part of human rights.

The Constitution as the fundamental law of ALBANIA, provides for the principle of equality for all citizens as guaranteed by law (Article 18.) Following this universal principle, men and women, being both subjects of the law, are legally treated equally, and have equal rights and obligations, but in real life the equality is not achieved. Gender equality may achieved when as a result of application of the law men and women have same gains and responsibilities.

Gender roles impact crucial personal decisions: on education, on career development, on working potentials, on family and on fertility. Such decisions do influence the progres of the society itself. Therefore, equal opportunities should be offered same to women and men in all sectors of life.

The empowerment of women and gender equality are not women issues, but respect for human rights. A sustainable, just and developed society can not exist without gender equality. Political, social, economic, cultural and environmental security among all citizens can be achieved when gender equality is a reality.

\section{Albanian Legal Framework on Equal Opportunities and Its Approach with International Standards}

\subsection{International acts on gender equality embraced by Albania}

Pursuant to clause 122/2 of the Albanian Constitution, "International agreements ratified by law have superiority over laws of the country that do not agree with them." Albania has already ratified many international instruments providing the protection of human rights, guarantees for gender equality and the fight against gender based violence. Such acts become part of Albanian legal system once the same are approved by the parliament and be published in Official Gazette.

One of the most important international instruments ratified by Albania since 11.05.1994 is the Convention "On the Elimination of All Forms of Discrimination against Women" (CEDAW), and its "Optional Protocol" worldwide regonized as the "Constitution of Women".

Other important international acts, Albania has adhered are:

Bejiing Platform for Action $1995^{1}$

${ }^{1}$ www.un.org/womenwatch/dawbeijing/platform: "The Platform for Action is an agenda for women's empowerment. It aims at accelerating the implementation of the Nairobi Forward-looking Strategies for the Advancement of Women and at removing all the obstacles to women's active participation in all spheres of public and private life through a full and equal share in economic, social, cultural and 
The platform covers following critical areas of concern:

- Women and Poverty

- Education and Training of Women

- Women and Health

- Violence against Women

- Women and Armed Conflict

- Women and the Economy

- Women in Power and Decision-making

- Institutional Mechanism for the Advancement of Women

- Human Rights of Women

- Women and the Media

- Women and the Environment

- The Girl-child

The Commission on the Status of Women ( "CSW") is a commission of the United Nations Economic and Social Council ("ECOSOC"). The CSW is the main policy-making body in global aspect focused exclusively to gender equality and advancement of women. Member States meet yearly at the headquarters of United Nations in New York to analyze progress on gender equality, define challenges, decide global standards and draft policies to promote gender equality and empowerment of women globally. UN Women is a unit that provide support to to CSW in its activity. The last report for Albania was submitted in 2014. The report was prepared by Albanian Ministry of Social Welfare and Youth.

ILO Conventions - Albania is responsible to report on advancement of labor rights and labor conditions to international mechanisms established by relevant international acts ratified by Albanian Parliament or adhered to by Albania. Gender issues and women rights with regard to labor questions constitute part of said report.

\subsection{Istanbul Convention ${ }^{2}$}

In accordance with Istanbul Convention the violence against women is a form of gender-based violence rendered against women. It is state obligation to address such violation with domestic mechanisms and undertake all necessary steps to: i) prevent gender based violence; ii) protect, reintegrate and rehabilitate the victims of such violence; and iii) condemn the violence authors. The convention states clearly that if girls and women are victims of gender-based violence, whilst state bodies fail to effectively address such problem, there exists no equality between women and men ${ }^{3}$.

\subsection{New York Convention ${ }^{4}$}

- Article 6 of this convention ${ }^{5}$ regulates the issue of the women and girls with disabilities ${ }^{6}$.

In addition, following the integration proces in the European Union, Albania and the European Union in June 12, 2006 have entered into the Stabilization and Association Agreement, (hereinafter referred to as SAA), which provides the obligation of Albania to guarantee equality between man and women. Following such obligations, Albania should

political decision-making. This means that the principle of shared power and responsibility should be established between women and men at home, in the workplace and in the wider national and international communities. Equality between women and men is a matter of human rights and a condition for social justice and is also a necessary and fundamental prerequisite for equality, development and peace. A transformed partnership based on equality between women and men is a condition for people-centered sustainable development. A sustained and long-term commitment is essential, so that women and men can work together for themselves, for their children and for society to meet the challenges of the twenty-first century".

2 The Council of Europe Convention on preventing and combating violence against women and domestic violence

${ }^{3}$ http://www.coe.int/en/web/istanbul-convention

${ }^{4}$ Convention "On the Rights of Persons with Disabilities"

${ }^{5}$ http://www.un.org/esa/socdev/enable/rights/ahc8adart.htm

${ }^{6}$ Art. 6: "States Parties recognize that women and girls with disabilities are subject to multiple discrimination, and in this regard shall take measures to ensure the full and equal enjoyment by them of all human rights and fundamental freedoms. 2. States Parties shall take all appropriate measures to ensure the full development, advancement and empowerment of women, for the purpose of guaranteeing them the exercise and enjoyment of the human rights and fundamental freedoms set out in the present Convention". 
approximate its legislation with acquis communautaire ${ }^{7}$. Equality is one of the objectives and founding principles of treaty for establishment of European Council and substantial rights of European Union. The obligations of Albania to integrate gender issues derive from five priorities provided by the Strategy for equality between men and women $2010-2015$ of the European Commission.

For the purpose of achieving the member status Albania should comply with the requests and recommendations provided by EU structures in Priority no.5 - Human rights. The progress of Albania in gender equality and human rights is subject of monitoring from EU structures, who deliver annual progress reports for Albania.

Albania acquired the status of candidate country in June 2014 and its obligation is to comply with legal and regulatory provisions of EU in gender issues and domestic violence ${ }^{8}$.

- In 2005, Albanian Government ${ }^{9}$ adopted the "National Plan for the approximation of legislation with EU law and the Implementation of the SAA"; This plan provides for the measures to be undertaken related to the fight against domestic violence and gender based violence, as well as achievement gender equality.

International acts influenced positively for adoption of effective laws that guarantee equal opportunities for men and women and relevant institutional mechanisms that gurantee gender equality in different sectors of the country. Notwithstanding the above, in order to have expected results from this very advanced legislation, it is necessary to assure sustainability and increase of institutional capacities, to strengthen the intersectorial cooperation, to draft effective gender based budgets and provide for effective monitoring mechanisms to address inequalities and boost women advancement status in the society.

\subsection{Strategic policies and domestic legal framework for gender equality and protection from gender based violence}

Albanian Government adopted in 2007 the "National Strategy for Gender Equality and Domestic Violence", and its Implementation Plan $2007-2010^{10}$. This marks the first governmental strategy for this field and its objectives were focused on strengthening governmental mechanisms at national for implementation and monitoring the strategy and the setting up of Equal Opportunities Commissions at local level and a responsible clerk for gender equality in each local unit.

In 2011, Albanian Government approved "National Strategy for gender equality and the reduction of gender-based violence and domestic violence, 2011-2015", and an action plan for its implementation ${ }^{11}$. The above act was drafted based upon consultation with many civil society actors, representing active organizations for gender equality and the protection from gender based violence.

During 2014, the strategy approved in 2011 is revised and focused on: i) gender equality and ii) fight against gender based violence. There are set four priorities by this revised strategy such as strengtheneing legal and institutional mechanisms; political empowerment of women; women economic empowerment; fight against gender based violence.

Ministry of Economic Development and Trade, ("MEDT"), recently launched the Action Plan for women entrepreneurship 2014 - 2020, in Albania, approved by ministerial order in May 2014. The action plan implies support for women in five main pillars: i) incentive policies for women entrepreneurs; ii) education development and capacity building; iii) increased access of women entrepreneurs in financial services; iv) establishment of the network of partners in support to women economic development; v) support for women in rural areas. The implementation of action plan is under monitoring of the MEDT in cooperation with the advisory board established by ministerial order. In addition, Minister of MEDT has approved the Fund in the Support of Women Entrepreneurs at the amount of 30,000,000 ALL with allocation term of four years. AIDA - Albanian Investments Development Agency exercising its activity under the supervision of MEDT is the responsible entity to administer and monitor the application of this financial fund.

The most recent strategy for promotion of employment and professional skills $2014-2020$ is approved by the Ministry of Welfare and Youth on beginning of 2014. This strategy sets clear objectives, inter alia, on: promotion of social entrepreneurship and economic empowerment of women (objective C2); reform of the financing scheme and administration of jobs market and professional education systems (objective D1); reformation of Albanian frame on professions (objective D3); modernization of legal framework on professional education for youth and adults (objective D4);

${ }^{7}$ Raporti Kombëtar i Pozicionit të Grave dhe i Barazisë Gjinore në Shqipëri, MPÇSSHB dhe UN Women 2011 - http://www.un.org.al/ editor-files/file/news/National\%20Report-Status\%20of\%20Women\%20and\%20Gender\%20Equality\%20ENG.pdf

${ }^{8} \mathrm{http}: / /$ ec.europa.eu/social/BlobServlet?docld=6568\&langld=en

9 The decision no.137, date 13.05.2005

${ }^{10}$ Decision of the Council of Ministers no. 913, date 19.12.2007

${ }^{11}$ Decision of Council of Ministers no. 573, date 16.06.2011 


\subsection{Legal framework on political empowerment of women}

Albania adopted a law dedicated to gender equality in 2008, ("Gender Equality Law"). The involvement of women in the political life and their empowerment in the decision making process, has always been the main objective of the Albanian Civil Society actors and at the same time it represents a challenge and an obligation of public institutions in the process of the Integration of Albania in the European Union.

Further to what was provided and achieved with the Gender equality Law of 2008, there has been progress by enforcement the Law on the Election Code in 2008 (Law no 10019, dated on 29.12.2008) where was provided that for each election zone, there should be at least $30 \%$ of the listed candidates or /and one in the first three names should be from each gender.

This new legal framework brought for the first time the obligatory involvement of the women up to the level of $30 \%$ of the candidates list for each political party (Article 67/5). The failure to enforce this legal obligation, charges any political subject with penalties as provided in the Articles 175 of the Election Code.

The Election Code has undergone again alterations in the context of the electoral reform of 2013. The Civil Society Organization that were involved in this process pretended that the Alteration of the Election Code not only did not improve the existing status-quo but marked a regress in the legal framework.

Despite of many problems noticed in the enforcement of the obligatory quota of $30 \%$ of the women in the Political Canditates List, the provisions of the Election Code brought an increasing number of women elected as deputy in the Albanian Parliament, from 6\% in 2001 in 18\% in 2013 (three from which, or 37.5\% even elected chairman of the Parliamentary Commissions).

In relation with the increasing trend of the representation of the women in politics, it is important to mention the fact that 6 women are ministers (or 46.1\%) in the Government which was configured in September 2013 , in comparison with the previous government where women were represented by only 1 woman.

From 2013 there is noticed a tendency to trust the women holding leading positions in various public institutions (central and local). There has been noticed as well an increasing representation with 6 woman ambassadors (or $12.2 \%$ more compared to the preceding year) in the diplomatic missions in the years 2012-2013. The increasing involvement of the women and their empowerment has been present not only due to Albanian International Commitment s(example the ratification of international documents on the women rights) and the process of the membership in European Union , but as well as a result of the growing cooperation with international organizations and due to the role that Civil Society Organizations have played in the field of gender equality and the violence against women ${ }^{12}$.

The Election Code has been again object of revision as a result of the approvement of the new territorial configuration enacted from the Albanian Parliament in the July 2014 . Due to the aforementioned revisions, has been made possible the increase in the level of $50 \%$ of the presence of women in the political candidates list for city councils all over Albania. As a result of these new provisions in the Election Code, today the percentage of the women acting as counsels in country range is $31 \%$ in comparison to $13.8 \%$ that was in the previous Councils.

The cooperation with women elected as deputy or other women holding important public positions in decision making institutions, is considered an important aspect on the purpose of further growing influence of the women with respect to their status and rights. The powerful women have many opportunities to make the advocacy on the women rights and gender equality through many legal initiatives and proper administrative measures.

\subsection{Legal framework on gender equality}

Gender equality law ${ }^{13}$ sets the main principles of equality between men and women in all wakes of public and private life and aims to: i) ensure efficient protection against discrimination of grounds of gender; ii) define safeguards for equal opportunities between men and women, in order to eliminate gender-based discrimination; iii) define the responsibilities of state authorities - at all levels, in drafting and implementing legislative acts and policies that support gender equality.

Gender equality law stipulates that gender mainstreaming shall be the approach to ensure gender equality in society, by reflecting the perspectives of all genders into the law-making, policymaking, planning, implementing and monitoring processes. It also covers discrimination and harassment, and provides for special temporary measures for

\footnotetext{
12 The Albanian Report 2014, on the fulfillment of the Obligations of the Acting Platform, Bejing

${ }^{13}$ Law no. 9970, dated 24.07.2008 "On gender equality in society"
} 
guaranteeing at least 30\% representation of the under-represented gender in political and public decision-making position for the least represented gender. The Gender equality law addresses gender equality and protection from discrimination in education, employment and media, whereas it explicitly mentions the need to estimate unpaid labour. Furthermore, the Gender equality law makes generation of gender-based statistics by State bodies compulsory, and provides for the establishment of bodies and institutional mechanisms devoted to advancing gender equality.

Government decision "On the approval of the national strategy on gender equality and reduction of gender based violence in families, 2011-2015 and of the action plan for its implementation 14";

Instruction ${ }^{15}$ of the Minister of Labour, Social Affairs and Equal Opportunities which provides for a series of quantitative and institutional monitoring instruments for the implementation of the Albanian legislation under gender equality perspective.

Government Decision"16 "On gender mainstreaming in the Medium Term Budget Programme" according to which all central institutions, as of 2013 , must set in their budgets measurable objectives on gender equality.

The Electoral Code of the Republic of Albania provides for the obligation to electoral entities to observe the gender quota (Articles 19 and 67). Under this legal instrument there have been adopted mandatory gender representation quotas in the electoral administration, second-tier commissions and the legislative organs (Parliament). The Electoral Code provided that both genders are to be represented in the multi-name list of candidates for MPs and this provision was obligatory for each electoral zone, and both genders are to be represented in the first three names appearing in these multi-name lists. Whereas for local elections, one in any three consecutive names on the list must be from the least represented gender. The Electoral Code has clear sanctions against political parties in case they fail to meet the gender quota in the list of candidates for MPs, i.e. otherwise any of them would be denied the multi-name list and consequently lose their right to participate in the elections. The Electoral Code, in 2015, was subject of revision given the approval of new territorial division of the country approved by Albanian Parliament through Law no.115/2014, dated 31.07.2014. Hence, the women representation in political parties' candidates list for city councils is $50 \%$ instead of $30 \%$ that was before.

- Law "On measures against violence in family relations", 17- having as purpose "to prevent and reduce domestic violence in all forms, through appropriate legal measures, and to guarantee protection through legal measures to members of the family who are subject to domestic violence, paying particular attention to needs of children, the elderly and the disabled".

- A potential or a victim of gender based violence may obtain from the court an order of protection that guarantees measures to prevent violence. Such order and relevant issuing procedures are specified in Law on "The measures against domestic violence". The district court is the competent authority to issue protection order, which has a maximum validity term of 12 months. Although the court's decision to issue protection order may be appealed in the Court of Appeal, it is an executive title and should executed by the bailiff office, according to the provisions of the Code of Civil Procedure (Article 510 / E, 516 / ce following).

Following the approval of Law against domestic violence in 2006, awareness and public confidence in domestic violence legislation and assistance to victims and survivors of domestic violence has been increased. The number of claims for protection orders has increased any year. ${ }^{18}$

In February 2011, the Council of Minister approved the decision "On the mechanism of the coordination of work for the referral of cases of violence in family relations and its way of procedure"19. It paves the way for the settlement of problems and deficiencies found in the cooperation and coordination of efforts against domestic violence. This document sets out a multi-disciplinary approach to assist victims of domestic violence.

Decision of Council of Ministers20 "On setting the standards for social care service provided to victims of domestic violence in public and non-public residential centers" - which aim to provide improved standards for the victims of domestic violence and their families.

- Decision of Council of Ministers "On eligibility criteria and documentation required for admission of persons in

\footnotetext{
14 Decision of Council of Ministers no. 573, dated 16.06.2011

15 Instruction no. 1220 , dated 27.05.2010

${ }^{16}$ Decision of Council of Ministers no. 465, dated 16.7.2012

17 Law no. 9669, dated 18.12.2006

18 In 2005 there were no protection orders; 1234 orders in 2010, 1562 in 2011, and doubled number in 2014.

${ }^{19}$ DCM No 334, dated 17.02.2011

20 Decision of Council of Ministers no. 505, dated 13.07.2011
} 
residential public and non-public social care institutions"21 - which regulates inter alia the criteria for placement of persons in residential centers where social care is provided.

- Law on "On protection against discrimination"22 - guarantees the principle of equality on grounds of "gender, race, colour, ethnicity, language, gender identity, sexual orientation, political, religious or philosophical beliefs, economic, education, or social situation, pregnancy, parentage, parentage responsibility, age, family or marital condition, civil status, residence, health status, genetic predispositions, restricted ability, and affiliation with any particular group or any other reasons". Law on protection against discrimination ensures the right of any person for: i) equality of rights by the law and equal protection by law; ii) equality of opportunities to exercise rights given by law, enjoy freedoms and acess to public life; iii) effective protection from discrimination and from any form of conduct that produces discrimination. Law defines the Commissioner for Protection against Discrimination as an independent body that safeguards protection against discrimination carrying out an activity of monitoring with powers of imposing sanctions for protection against discrimination.

\subsection{Prime Minister's Order23 "On establishment of the National Centre for Treatment of Victims of Domestic Violence".}

"Criminal Code of the Republic of Albania", ${ }^{24}$ (hereafter also referred to as the "Criminal Code") - which provides for the qualification of the domestic violence as a criminal offence. Thus, according to article 130/a of the Criminal Code, "domestic violence, including beating, threat and intentional injuries, shall be punishable by imprisonment up to five years". On the other hand, the Criminal Code includes the systematic psychological and economic abuse, as well releases victims of domestic violence from the obligation to file a criminal suit in the case of "light physical injuries". Hence, as per article 121/a of the Criminal Code the "repeated threats and/or repeated actions intended to cause a continuous and grave sense of anxiety or fear on a person's security, the security of their relatives or the security of a person with whom they are related sentimentally, or intended to force them to change their lifestyle, shall be punishable by imprisonment from 6 months to 4 years". When this offence is committed by a former spouse/cohabitant the sanction shall increase by one-third. When this offence is committed towards a minor, a pregnant woman, or a person unable to defend himself, or by a person wearing a mask or is accompanied by possession or use of weapons, the punishment shall increase by half. Hence, the Criminal Code qualifies as criminal offence any forced sexual intercourse with adults or husband/partner without their consent, making it punishable from 3 to 10 years of imprisonment. Besides, sexual violence through actions of sexual type on the body of another person using material objects constitutes a criminal offence and is punishable by 3 to 7 years of imprisonment; when in cooperation against many persons and repeatedly, or against children from 14 to 18 years old, it is punishable by 5 to 15 years of imprisonment. Furthermore, when this offence is committed on a minor less than 14 years old, or a minor not yet in his/her sexual maturity, irrespective if there is any force involved, such offence is publishable by not less than 20 years of imprisonment; if this criminal offence leads to victim's death or suicide, it is punishable by not less than 25 years of imprisonment.

The Criminal Code has also adopted another provision for protecting the women from violence and, specifically, the qualification of the sexual harassment i.e. sexual behavior violating human dignity with any means or form resulting in a threatening, hostile, degrading, humiliating or offensive environment, as criminal offence and, as such, punishable by 1 to 5 years of imprisonment. When committed in cooperation and repeatedly, or against children, this offence is punishable by 3 to 7 years of imprisonment. On the other hand, the legislator stipulated that encouragement, intermediation or offering remuneration for persuasion to prostitution is punishable by 2 to 5 years of imprisonment; if this offence is committed against minors, against many persons, or against persons within close consanguinity or by taking advantage of an official relationship or conducted on collaboration or more than once or by persons who have state and public functions/duties, is punishable from 7 to 15 years of imprisonment.

Law "On Clemency"25 - defines the criteria and procedures for granting the clemency to the person imprisoned. The application of this law excludes the perons who have committed criminal offences against pregnant women, or for criminal offences under article 114/a "Exploitation of prostitution in aggravating circumstances" of the Criminal Code,

\footnotetext{
${ }^{21}$ Decision of Council of Ministers no. 425, dated 27.06.2012

${ }^{22}$ Law no. 10221, dated 4.2.2010

${ }_{23}$ Prime Minister's Order no. 36, dated 18.03.2011

24 Law no. 7895, dated 27.01.1995

${ }^{25}$ Law No 10295, dated 01.07.2010
} 
under article 114/b "Trafficking of Women" of the Criminal Code, and other criminal offence against minors/children. During the application of the Law on Clemency, no exoneration has been approved in favor of persons sentenced for criminal offences against women or children.

Law "On social assistance and services"26, which provides that the economic aid may be withdrawn not only by the head of the household, but also from abused women, in case a protection order is issued in the latter's favor. Hence, under this law, women are entitled to benefit and have access to economic assistance even when their spouse has filed for divorce and there is not yet a final court decision.

- Law "On legal aid"27, has widened up the categories of entities entitled to legal aid including also: i) victims of domestic violence or victim of human trafficking or victims of court cases related to these criminal actions; and ii) the persons who enroll in social protection programs or are eligible under the same. In 2013, the Law was subject to some amendments by means of Law nr.143, providing legal aid from state budget funds to those individuals implied in court proceedings who: i) fulfill the criteria to benefit from social protection scheme, and ii) are victims of domestic violence or gender violence.

- Law "On prevention and suppression of organized crime and trafficking through preventive measures against property" 28 expands the scope of action over other criminal offences and gives more powers to the judiciary to seize crime proceeds, including those generated from trafficking of human beings.

- General Director of State Police Order29 "On the coordination of work among central and local bodies in the fight against trafficking in human beings and in the identification of trafficking victims".

- Law "On some amendments to Law 'On social assistance and services"30. Pursuant to this law, the Ministry of Labour, Social Affairs and Equal Opportunities transfers funds (for nutrition purposes) to the Social Protection Programme for beneficiaries (Victims of trafficking) that obtain services from non-public service providers (Shelters/Centres). This law also provides that the victims of trafficking, in addition to the social services provided to them during their accommodation in the reception and re-integration shelters, shall be entitled to economic aid in the period between leaving the residential centre and finding an occupation.

- Government Decision "On Standard Operation Procedures for the identification and referral of victims / potential victims of Trafficking" ${ }^{31}$. Standard Operation Procedures standardize identification and referral actions, including the package of services for the (potential) victims of trafficking.

- Government Decision "On treatment of victims of trafficking and health services provided to this category"32 which provides that the victims of trafficking are entitled to free health care through the Health Insurance Institute. This Decision was approved following several months of work and cooperation among the AntiTrafficking Unit, Ministry of Health, Health Insurance Institute, and shelters for victims of trafficking.

- Order of the Minister of Labor, Social Affairs and Equal Opportunities no. 2498 dated 16.12.2008, as amended by order no. 2271 dated 8.12. 2009 "On the establishment of the inter-ministerial working group" which sets up this advisory body for the identification and establishment of gender statistics in support of policies for monitoring of gender equality in Albania, in line with Law on GE.

- Decision of Council of Ministers no. 27, dated 11.01.2012, "On promotion of Employment of women and girls from special groups;

The Albanian Government has undertaken the revision of all the applicable legislation through gender approach. As a consequence of such process, the latest amendments of the Labor Code entered into in June 2014 provide for the regulation of the cases of sexual harassment in working place, maternity leave for men, protection for pregnant women and children, ets. It is also reported that the Albanian Government intends to amend all legal provisions into force that represent inequalities and fail to properly address the situation of women.

\footnotetext{
${ }^{26}$ Law no. 10399 , dated 17.03.2011

${ }^{27}$ Law no. 10 039, dated 22.12.2008

${ }^{28}$ Law no. 10192, dated 03.12.2009

${ }^{29}$ Order no. 69, dated 25.01.2010

30 Law no. 10252, dated 11.03.2010

${ }^{31}$ Decision of Council of Ministers no. 582, dated 27.07.2011

32 Decision of Council of Ministers no. 395, dated 20.6.2012
} 


\section{Mechanism of Gender Equality in Albania}

- Commission for health, labour and social issues - is a commission within the Parliament of Albania handling, mongst the others, also the issues of gender equality.

- Department of Social Inclusion Policies and Gender Equality (DSIPGE) - is a Department at the Ministry of Social Welfare and Youth. This Ministry is the responsible government body for promotion of gender equality in Albania. DSIPGE is a structural part of the Ministry, originally (in 2006) vested with the tasks of formulating and development of policies for gender equality and reduction of domestic violence. Currently, DSIGE mandate is to mainstream programs of social inclusions with gender equality.

- National Council of Gender Equality - is an advisory body for gender equality established by order of Prime Minister 3/2009 pursuant to Law no 9970/2008. The Minister of Social Welfare and Youth leads the Council in his quality as the chairman. This national advisory body is composed by 9 vice ministers' dhe 3 represatives of civil society. This council provides relevant opinions and recommendations on approval of legal and sublegal acts on gender equality, various reports on monitoring gender equality application and gender based violence; in addition, such structure gives recommendations to be taken into considerations by local and central institutions during exercition of their tasks on promotion and protection of gender equality and fights against domestic violence.

- Commissioner for the Protection against discrimination (CPD) - CPD was created in accordance with the Law "On the protection from discrimination", as an independent institution which ensures the effective protection from discrimination and any other form of behavior that incites discrimination as provided by specific law. CPD is responsible to examinate the complaints of subjects which claim to have been victims of discriminatory behaviors, both from the public administration and from private subjects. In addition, the Commissioner undertakes administrative investigations after receiving information for violation of the discrimination law, and performs monitoring of law enforcement. CPD issues recommendations that should be executed by private and public subjects, otherwise sanctions are applied as provided by law. Notwithstanding, the sanctions, CPD may oblige the subjects to undertake actions for informing and raising the awareness of the community, public administration bodies and private entities, to promote the principle of equality and non-discrimination.

- Referral mechanisms - are gender employees in local and central bodies established pursuant to law on gender equality. Gender employees are civil servants educated with gender issues and principles, gender budgeting, gender equality laws etc. They exercise their functions in any local and central unit of public administration. Up to september 2013, only three ministries had appointed gender employees; all other ministries have focal point on gender issues; only in 17 units of local authorities there are offices for gender equality; in 46 other local units focal point on gender issues are established.

- Ombudsman - is an institution not listed as a mechanism for gender equality by the public administration relevant reports. Notwithstanding the fact that gender equality legal framework does not provide specific tasks for Ombudsman, taking into consideration that i) the tasks conferred by law to the Institution for the protection and promotion of human rights, ii) gender equality is substantial part of human rights, it is in the very substantial nature of the work of Ombudsman to play an imense role for achieving gender equality in the country.

In light of the above, it results that in Albania there are some nechanisms for addressing gender inequalities, but there is no dedicated authority for this purpose, such as a national authority for gender equality, as it is in Portugal ${ }^{33}$ or in Croatia.

\section{Conclusions}

- Albania has an advanced legal framework on gender equality;

- Domestic laws imply international standards for protection of women rights;

- Albania has established mechanisms to address inequalities;

- Gender equality and women empowerment is still a challenge in Albania, especially with regard to women economic empowerment; 
- It lacks coordination between public actors and relevant budgets to have expected results from legal framework on gender equality;

- There is no national mechanism for gender equality in Albania.

\section{Recomandations}

In consideration of the above, in my opinion Albania and its institutions need to:

- Strengthen and coordinate the cooperation for effective implementation of legal framework on gender equality and prevention and protection from gender based violence;

- Define and adopt gender mainstreaming policies in all areas of life;

- Prepare, adopt and implement effective gender budgets;

- Develop the idea of having a dedicated national authority for gender euqality in Albania refering to best role models in EU;

- Establish rule for active participation of women in decision making, instead of representation.

\section{References}

International Council of Women: http://www.icw-cif.org

United Nations: Commission on the Status of Women: http://www.undp.org/fwcw/csw

United Nations: Committee on the Elimination od Discrimination against Women: http://www.un.org/DPCSD/daw/CEDAW

United Nations: Division for the Advancement of Women

Raporti i Shqipërisë për zbatimin e Platformës së Pekinit për Veprim www.mireqenia.gov.al

Constitution of Albania http://www.parlament.al

Law nr. 9970, dated 24.07.2008 "On gender equality"

Law nr. 9690, dated 18.12.2006 "On measures against violence in family relations"

Law nr.10221, dated 04.02.2010 "On protection from discrimination"

Electoral Code

Criminal Code

Raporti Kombëtar i Pozicionit të Grave dhe i Barazisë Gjinore në Shqipëri, MPÇSSHB dhe UN Women http://www.un.org.al

Strategjia për barazinë mes grave dhe burrave 2010 - 2015" - Komisioni Europian, Shtator 2010.

"Femra dhe Meshkuj në Shqipëri, 2013, INSTAT http://www.instat.gov.al/en/publications/books.aspx

Konstatimet përmbyllëse të Komitetit për Eliminimin e të Gjitha Formave të Diskriminimit të Grave, për Shqipërinë. CEDAW 2010. http://www.ohchr.org/english/bodies/CEDAW/CEDAWs46.htm

UNESCO Venice Office, Prill 2014. http://stats.uis.unesco.org/unesco/tableviewer/document.aspx?Reportld=143

Banka e të dhënave të Bankës Botërore, http://www-wds.worldbank.org/external/default/WDSContentServer/WDSP/IB/2013/10/17

Dhuna në familje në Shqipëri: Vrojtim kombëtar me bazë popullatën 2013, http://www.instat.gov.al/en/publications/books/2013/domesticviolence-in-albania-2013.aspx

Raport i Progresit për Shqipërinë 2013, Komisioni Europian http://www.un.org.al/editor-files/file/Harmonized_Indicators_ENGLISH.pdf http://www.instat.gov.al/media/171075/revised___albania_dhs_2008-09_-_mar_05.pdf 
